\title{
Moral Dimension of Javanese Forgiveness in Serat Wedhatama and Serat Nitiprana
}

\author{
Suharsono $^{1}$, Rizal Mustansyir ${ }^{2}$, Rr. Siti Murtiningsih ${ }^{3}$ \\ (msuharsono@gmail.com¹,mustansyir@gmail.com²,st_murti@yahoo.com.sg ${ }^{3}$ ) \\ ${ }^{1}$ Psychology Faculty at Universitas Katholik Soegijapranata, Semarang, Indonesia \\ ${ }^{2,3}$ Philosophy Faculty at Universitas Gadjah Mada, Yogyakarta, Indonesia
}

\begin{abstract}
This paper aims to critically analyze the moral dimensions of Javanese forgiveness in Serat Wedhatama by Mangkunegara IV and Serat Nitiprana by R. Ng. Yasadipura. Data analysis using Dilthey's hermeneutic method, and interpretation of results using Javanese Ethics theory from Frans Magnis Susena and Ethics theory from Driyarkara. The results of data analysis show that the nature of Javanese forgiveness in a moral perspective is the embodiment of virtuous human character. Forgiveness for virtuous humans comes from inner peace. Someone who has inner peace is not only able to overcome or at least control negative emotions and evil desires (not revenge), but also able to do good (compassion) to the wrongdoers. Forgiveness for virtuous people who have inner peace is a process or the result of a thoughtful process, the right decision, and persistent and resilient in application
\end{abstract}

Keywords: Moral Dimension, Javanese Forgiveness, Virtuous Human Character, Inner Peace

\section{INTRODUCTION}

Forgiveness or in Javanese is called by various terms, such as "aksama (ngaksama), pangaksama, pangaksami, pangupaksama" or "apura, sêpura, ingapura, pangapura, pangapuntên" [1] by the thinkers (philosophers) especially among ethicists (moral philosophy) are recognized as objects of philosophical study which are increasingly popular and fairly sexy, but also are recognized as controversial and dilemmatic. Some thinkers urgue that forgiveness in an ethical perspective is categorized as one type of virtue or at least part of the virtue of mildness [2]-[6] . Some other thinkers (philosophers) argue that forgiving too quickly or forgiving without involving certain conditions, such as the dignity of the victim, apologies from the perpetrators, and the presence of other moral values are at risk of morally reprehensible; human mark is weak, dwarf (mental slave), and even considered useless (useless) because it is not effective as a means of overcoming anger or hatred [7]-[9].

The controversy about the moral status of forgiveness - on the one hand is considered good and on the other hand can be mired in humiliation or bad - is also portrayed clearly in the context of Javanese culture and has a strong influence on the daily lives of Javanese people. The controversy about the moral status of forgiveness in the context of Javanese culture can be found easily at the level of ideas or thoughts or at the level of concrete behavior. Disagreements at the level of ideas about the moral status of Javanese forgiveness can be found among a variety of written and unwritten literary works. The Mahabharata story especially in the Bharatayudha war section is one of the phenomenal examples of no 
forgiveness or forgiveness is morally blamed. The Kaurava as a symbol of evil humans; bad or morally corrupt is considered worthy of destruction, destroyed, and must be crushed to the roots [10]. No forgiveness is considered the right and morally best choice when evil desires (nafsu angkara) are rampant; self-interest or selfishness takes precedence, and the interests of others are ignored, even intentionally taken away or eliminated. In short, wrongdoers cannot be forgiven when their actions violate the values of humanity, justice and the prosperity of living together. Mulder argues that in wayang stories there is no forgiveness and only one choice; win or lose and die [11].

Other examples of forgiveness at the level of ideas appear in the form of folklore, such as the story of Mangir Wanabaya (rewritten in the form of a novel by Pramoedya Ananta Toer, 2000) and the story of Keris Empu Gandring. The folklore of Mangir Wanabaya and Keris Empu Gandring seemed to give a moral message that the most extreme punishment in the form of loss of life (murder), could be carried out by sadistic ways to the wrongdoers. Sadistic retaliation to wrongdoers can be justified or at least understandable when aiming for the defense of self-respect and or preservation of institutional authority [12]. Humiliation of personal honor (ora diwongé) or feeling that one's existence as a human being is not valued (dianggêp wis dudu manungsa) for Javanese means to lose everything. The existence of oneself as a person with dignity is decayed or destroyed and disappeared without a trace. "Aji Godhong Jati Garing" is a Javanese proverb to describe the state of life (kahanan urip) without self-worth. Loss of dignity (self-esteem) because it is mistakenly treated by others is used as a justification (legitimacy) in retaliation by justifying all means.

The assertion that forgiveness is morally considered not the best choice in responding to the mistakes of others arises in the form of proverbs (paribasan, bêbasan; unèn-unèn) and among them which are quite popular in the daily life of Javanese people, are as follows; "utang lara nyaur lara utang pati nyaur pati, dadi godhong êmoh nyuwèk, dadi banyu êmoh nyawuk, ilang-ilangan êndhok siji, tijitibèh; mati siji mati kabèh, tumpês kélor, sêdumuk bathuk sênyari bumi diréwangi toh pati dilakoni" [13]. Mistreatment from others should not be condoned, not be excused, not be forgetted, not be justified, not be forgiven, or not be pardoned. Retaliation is an obligation (must) or at least is permitted (not prohibited) and is not taboo if done in more cruel ways. Revenge becomes the antidote to hurt; considered the best way to restore dignity. Feelings of satisfaction and joy when offenders suffer are the energy behind revenge. Javanese proverb "wong nandur bakal ngunduh" or "ngunduh wohing pakarti"; good deeds give birth to good or vice versa bad deeds give birth to ugliness are the basis of justification for retaliation.

The reality or facts of revenge are easily found in the practice of everyday Javanese society. One phenomenal example of revenge - no forgiveness - in the form of termination of social relations is "jothakan; nêgnêngan ". "Jothakan; nêngnêngan "is silence (termination of communication) and accompanied by circumvention (termination of interaction) and can last a lifetime and may even be passed on to children and grandchildren because their dignity is insulted, humiliated or abused by others [14]. "Jothakan; nêngnêngan "aims not only to isolate (exclude) but also to erase the existence of the offender from the psychological life of the victim. A saying "dadi godhong êmoh nyuwèk, dadi banyu êmoh nyawuk" is a description that contains a message for anyone that hatred because of self-humiliation (hurt) will never shift or transform into feelings of love (seneng, tresna). In other words, the breakdown or fracture of social relations due to self-humiliation (hurt) is difficult or impossible to be repaired or reconnected. Mass killings or massacres of followers of the Indonesian Communist Party (PKI); especially in the regions of Central Java and East Java are other examples of revenge (no forgiveness) for those who have done wrong or are considered guilty. Massacres or 
killings of followers of the Indonesian Communist Party and have a very strong nuance as a form of revenge - expressions of hatred and anger are very strong - predicted to reach 500 thousand people [15].

The above description gives a glance information that forgiveness does not seem to be fully appreciated as the best choice in responding to the mistakes of others. The moral status of forgiveness (apart from religious perspectives) is still doubtful because it can be interpreted as the embodiment of a weak character (asor bebudené). Forgiveness shows moral deficiency or weakness rather than showing admirable or commendable moral quality. The elements of forgiveness, such as the ability to overcome or at least control negative emotions and evil desires and willingness to do good to the offender are considered not virtue but a personal image of a dwarf soul (slave mentality) and require moral flattery. The nature of forgiveness may still be considered synonymous with condonation, excuse, forgetting or even justification for mistakes. Recognition of the wrongdoings of other parties without retaliation is considered to be a form of conformity to crime or non-compliance with justice and social order. No retaliation or claim for compensation for the wrongdoing of another party (forgiveness) is considered a form of selfishness; one's own welfare takes precedence while shared prosperity is ignored.

Based on the consideration that forgiveness is still open to the possibility of negative moral status; morally bad or despicable because it is considered a picture of human character is weak (do not care or remain silent when self-respect is harassed by other parties), and also do not care about other moral values, such as justice and social order, then a critical study of the moral dimensions of Javanese forgiveness in Serat Wedhatama and Serat Nitiprana get its urgency. The purpose of this study is to analyze the moral dimensions of Javanese forgiveness in the Serat Wedhatama and Serat Nitiprana. The findings are expected to provide a more substantive picture of the moral values of Javanese forgiveness so that the hurt because selfrespect is being harassed by others does not become a trigger for revenge but rather opens up space to continue to do good. Forgiveness is a very strong humanitarian energy to create a civilized life; overcome the past full of anguish and break the cycle of endless revenge, for the sake of the present and a better future; the happiness of life for yourself and others.

\section{THE MORAL TEACHING OF JAVANANESE FORGIVENESS}

The idea of forgiveness as a good moral teaching (pitutur luhur) in Serat Wedhatama by Mangkunegara IV and Serat Nitiprana by Raden Ngabehi Yasadipura) are as follows [16][19]:

Angkara gung, nèng angga anggung gumulung, Gegolonganira, Triloka lêkêré kongsi, Yèn dèn umbar ambabar dadi rubéda (bait 34). Béda lamun kang wus sêngsêm rèh ngasamun, Sêmuné ngaksama, Sêsamané bangsa sisip, Sarwa sarèh saking mardi martatama (Pupuh Pocung bait 34 dan 35).

(Big negative emotions and evil desires (anger) are entirely on the person himself, which includes three kinds of nature, if negative emotions and evil desires are allowed to create physical and mental misery. In contrast to people who are already interested in a calm atmosphere of inner life, all attitudes and behavior signify forgiveness to others who do wrong, all-patience that comes from a good heart, cold, calm or virtuous) 
Sabarang tindak tanduk, tumindaké lan sakadaripun, Den ngaksama kasisipaning sêsami, Sumimpang ing laku dur, Hardaning budi kang ngrodon (Pupuh Gambuh bait 74)

(All acts or deeds carried out must not be haphazard or rushed. Act modestly or according to ability and forgive others who do wrong, avoiding disgraceful actions,release a big evil character)

Jroning Kitab Sipatul Ngulaki, tandhaning wong kang kurang budinya, ana pratandha awaké, solah pangucapipun, kang kanggonan jatining budi, yèn katêkanan balak, ing sariranipun, winêlas ing kabêcikan, mring kabuka marang ing sasamisami, wong luput ingapura (Pupuh Dhandhanggula bait 07)

(In the book Sipatul Ngulaki, the sign of a person who is humble, there is a sign in his body, all his words, and a virtuous person, when he experiences disaster because of wrongdoing by other parties, he responds with kindness, open hearted to all people, wrong person forgiven).

The term forgiveness in the Serat wedhatama is "ngaksama", while in the Serat Nitiprana is "ingapura". The terms "ngaksama" or "pangaksama; pangaksami; pangupaksama" comes from the basic word "aksama" (Kawi language), and the terms "ingapura" or "pangapura; pangapunten" comes from the basic word "apura; sepura". The terms "ngaksama" and "ingapura" in principle are no different because the two terms are identical, that is "dilunasaké kaluputané (wrongdoing has been removed); lunasé paukumane panggawé ala (the punishment for bad deeds has been removed); ora diukum (not punished), ora dipidana (not convicted), ora didenda (not fined)" [20]. If the term "ngaksama" or "ingapura" is understood literally (according to the dictionary meaning), then the meaning of the two terms (ngaksama; ingapura) refers to a psychological response or certain behavior so that the mistake (sin) or bad deeds of the other party are eliminated or destroyed without a trace. If the other party's mistake is like a debt and must be paid, then forgiveness becomes a substitute for the debt. In other words, forgiveness makes all the consequences of wrongdoing, whether in the form of punishment (criminal; torture) or compensation payment that must be borne by the offender deemed to have paid off. In short, forgiveness is the cleansing of mistakes (sins) or the elimination of bad deeds so that the wrongdoers are free from moral defects. The wrongdoers can again appear morally clean and deserve to be re-valued as human beings (personal) with dignity.

The personal characteristic of good character (bêcik) or virtuous (luhur bebudèné) in the Serat Wedhatama and Serat Nitiprana is its willingness to forgive the mistakes of others. This willingness to forgive is a distinguishing characteristic between a person with bad character (ala, candhala) or low-minded (asor bebudèné) and a person of good character (becik) or virtuous. Willingness to forgive is evidence of the ability to overcome or at least control the lusts of desire (such as the desire for revenge) that surges in him because of the mistaken or bad treatment of others. In other words, forgiveness for virtuous individuals is a very significant sign that silence or inner calm as the source of life's happiness has been firmly planted and becomes its most valuable possession. In contrast to personal bad character or low-minded (asor bebudèné); not forgiveness but revenge is the best choice when he is mistreated by others. Suseno (1993: 140), a person with a bad character in the sense that he is still dominated by negative emotions or evil desire (angkara murka) can be read from the whole attitude and behavior, such as; want to appear dominant or have to be the first person (nêpsu mênangè dhéwé), the truth is claimed to be only his (nêpsu bênêré dhéwé), and his own 
needs are championed (nêpsu neededé dhéwé) [21]. The desire to harm others and rejoice when others suffer is another characteristic of the nature of arrogance [22].

Humans of bad character have harsh feelings and egoistic. Expressions of rough (harsh) feelings (or negative emotions), such as anger, hatred, malice or envy, or sadness and egoistic expressions such as feelings of dislike and desire to harm others (evil desires) can be read from the whole attitude and behavior. Certain behaviors (behavioral traits) that signify and express harsh feelings and egoistic through facial expressions (polathan), for example pouting (mbêsungut, njabrut, njêkêrut), grim (pêtêng, nyurêng, sirung, njêmbrung); through certain words or words that are demeaning, threatening, and insulting (nylêkit, braok, saru); through hand movements, or ways of sitting, and ways of walking aimed at making trouble (jail, mêtakhil, kakèhan polah, kêmaki, kêmlinthi, riwil; ora jênjêm, durung mênêm). If this turmoil of lusts is left out of control; not overcome or not controlled, it is not happiness but disaster will come and befall.

Humans with bad character contradict their attitude and behavior with virtuous person. Silence, serenity, and harmony of the mind or atmosphere of spiritual life that is calm because it is able to overcome or at least control arrogance - rough and egoistic feelings - is a source of happiness or the ultimate goal for virtuous persons. The wrong or bad treatment of others is not an obstacle to keep doing good to the wrongdoers. Forgiveness is not limited to overcoming or controlling evil desires, such as anger or hatred, and other negative emotions, but also fostering kindness to wrongdoers. Forgiveness for virtuous people is a guarantee that relationships between human beings are not interrupted by mistakes made and hatred or moral anger felt. The perpetrators of wrongdoing for individuals of noble or praiseworthy character are fellow human beings who will never be permanently denied their existence let alone be destroyed.

There is no permanent refusal or vicious retribution is evidence of the ability and willingness to survive (not fall) and try to get away from bad living conditions. Forgiveness means requiring in advance certain psychological conditions in order to be arrogant; desires for revenge or requests for compensation can be overcome or at least controlled so that they are not wildly expressed or out of control. This means patience (sarwa sarèh), sincerity, nrima, rila as a mirror of humility (andhap asor lan lêmbah manah) and followed by doing good deeds as a mirror of compassion (wêlas asih; ambêg wêlasan; ambêg paramarta) are prerequisites of forgiveness. Suseno quoted the opinions of Geertz (1981), Koentjaraningrat (1969), de Jong (1976), and Soetrisno (1977), explaining the notions of patience, sincerity, nirma and rila as follows [23]:

"Patience is a sign of a good human being (leader): he advances with caution, steps with trial and error, as if he stepped on a board whose strength is unknown. Patience means having a deep breath in the awareness that in due course good fortune will arrive. Nrima means accepting everything that comes to us, without protest or rebellion. Nrima should not be interpreted as the ability to swallow everything apathetically, but rather accept the conditions of life that are bad and in difficulty continue to react rationally by not falling (collapsing) and also not resisting in vain. Nrima demands strength to accept anything that cannot be avoided without allowing itself to be destroyed by it. Nrima's attitude gives endurance to also suffer bad luck. For those who have that attitude, it's a disaster to lose their misery. He remains happy in suffering and and concerned in joy. Ikhlas means "willing" or able to let go of his own individuality and fit into the great harmony of the universe as determined. Rila means the willingness to relinquish property rights, abilities and results of one's own work if that is the responsibility or fate demand ". 
So patience, sincerity, nrima and rila is a state of mental life (inner life) that is able to help overcome or at least control arrogance. Patience as a prerequisite for forgiveness is a psychic space that contains the hope that bad conditions due to wrong treatment of other parties can shift, change or transform into a good state even better. Patience means not limited to suppressing or controlling arrogance, but also trying to overcome them, that is, brave stepping carefully to release the grip of arrogance. Nrima in the context of forgiveness is the ability to accept and admit sincerely the mistakes of others and be able not to retaliate or ask for compensation for those mistakes. Acceptance of wrong treatment and its bad effects (nrima) does not mean that mistakes are left (turning a blind eye to mistakes), mistakes can be tolerated, mistakes are intentionally forgotten (allowed to pass over time). Patience and nrima is a psychic space to keep thinking clearly about the main elements of forgiveness, such as acknowledgment of mistakes, the ability to choose the right response to mistakes, and the ability to release negative emotions and evil desires. Ihklas is a psychic space associated with the belief that there is involvement of divine power in human life. Ikhlas refers to psychological conditions that do not revolt when self-dignity or self-respect as the most valuable possessions are demeaned by others. Ikhlas is a sign of the ability to accept his nature as an imperfect human being; can do wrong to others or vice versa is treated wrongly by others. Rila is a psychological condition that allows the victim personally to be willing to give up his rights, such as the right to be treated well and fairly by other parties.

Prerequisites for forgiveness also involve the ability to do good; generous or compassion (wêlas asih; ambêg wêlasan; ambêg paramarta) to the wrongdoer. Generosity does not refer to pity to other parties especially to those who have done wrong or bad. Generosity or compassion does not refer to moral superiority; morally feel better, more noble, more praiseworthy than other parties, especially in front of those who are considered inferior, bad, evil, despicable because of their status as offenders. Serat Nitiprana teaches that the image of a virtuous human being (luhur bebudèné) is read and emanated from the kindness of sincere attitude and selfless actions based on patience of the heart [24]. The patience of the heart facilitates the attainment of inner peace (purity of heart) and inner peace radiates personal goodness (purity). Kindness from within the person will emit a light of kindness to others so that the punishment (doom) for mistakes (escape; escape) or bad perks (panggawé ala) can be rejected or removed. So generosity or compassion - doing good to others who have done wrong - is sourced or arises (mrêntul) from inner calm (purity of heart).

Generosity or compassion; the result of calmness, serenity, and harmony of the heart (purity of heart) is clear (bêning) - not polluted or dirtied by selfishness - so as to create coolness (ngasrêpi) and also radiate warmth. Generosity (wêlas asih) means transcending pity; a positive feeling that arises because it is triggered by the presence of bad life conditions in the form of suffering or misery of others. The desire to feel and be motivated to help ease the burden of suffering in others is the main energy of pity. Generosity is not only in the form of sympathy for the misery or misfortune of others, but encouragement of good will, namely; in the form of feelings of love (sênêng, trêsna) to others as human beings. Generosity in the context of forgiveness means a sense of self to take responsibility or to be actively involved in presenting coolness; calm, serene, peaceful, and warm; happy and excited so as to create an atmosphere of harmony based on respect for others as humans. Generosity as a personal expression of forgiving character (ambêg paramarta) shines concern for the welfare and happiness of fellow human beings without conditions. A compassionate person who is forgiving does not need an apology; marks of remorse and requests for compensation; a sign of repentance to the wrongdoer. In other words, forgiveness does not require violators to experience suffering or misery first. Generosity in the form of the ability to forgive sincerely - 
arising from good intentions - for the mistakes of others is a sign of a plenary personal or true knight [25]-[26].

Concrete forms of generosity (compassion) as a sign of forgiveness in the practice of everyday Javanese society are displayed in various ways. Ability to greet (sapa aruh), say certain words, both orally and in writing, such as; "It's okay, I have forgiven your mistakes" (orapapa, salahmu wis tak ngapura), "that which has passed let it pass" (sing wis ya wis), "don't repeat it again" (aja dibalèni), "calm appearance" (antêng) and shady faces decorated with sincere smiles", and "hospitality" (anjangsana, silaturahmi, sanja) are some examples of expressions of compassion (doing good) to the wrongdoers. The intrinsic meaning of the term "it's okay" (orapapa) when used at the beginning of the utterance or sentence "I have forgiven your mistakes" (salahmu wis tak ngapura) is "not despicable" (ora nista) or "not bad" (ora ala ) [27]. So the meaning of the term "orapapa" which means "ora nista" refers to the recognition of a mistakes, but the mistakes does not lead to adverse effects; trigger retaliation or demand for compensation. This means saying "orapapa" in recognition of the mistakes of others is a moral message that functions to self-affirmation that the impact of mistakes does not make self-dignity, or self-respect fall into disrepute. Kaesang's writing on his Twitter account is "yo ora popo (ora papa). Maafkan wae" is concrete evidence of the use of the term "ora papa" in recognition of the mistakes of others and retaliation or request for compensation is not the best choice of response type for the error.

Identical to the words "orapapa", calm appearance and shady facial expressions decorated with smiles are also used as an effective way of affirmation to remain strong so that they are able to think clearly and not dissolve in pain, sadness, anger, and hatred. The reason behind calm appreance and shady facial expression decorated with smile is a form of sincere acknowledgment that others mistakes or bad deeds are not a kind of permanent crime or a type of moral disability without room for improvement or recovery. Calmness, coolness, and smiles are a mirror of hope (optimism) for a better and more promising condition of life; present and future. This means that the wrong treatment of the other party is considered insufficient and also improper when responded only with pain, cry, and anger. Calmness, coolness, and smiles also give a strong message that the existence of the offender can still be accepted. In other words, calmness, coolness, and smile are a sign that there is no permanent rejection or cruel destruction to those who have made mistakes. So calmness, and the expression of a shady face decorated with a smile is a sign of feeling like (rêmên) and love (trêsna) and not a strategy of diverting attention from bad circumstances in order to obtain praise. Empirical facts show that smiling is recognized as a sign of forgiveness that is commonly practiced in the daily lives of Javanese people [28]. A smile for the Javanese serves as an opening key for communication and a sign of a happy and grateful person in his life. Stage (in Endraswara, 2016): 191), a smile for the Javanese is a way of salvation (dalan rahayu) [29].

Forgiveness in the form of concrete actions, other than through speech and body language (facial expressions), which is commonly practiced in the daily life of Javanese people is the ability to go on or stay in touch. The term anjangsana refers to visits to release longing or to stay in touch (to tie a cord of friendship or brotherhood), for example to a neighbor's house, family, old friend or friend [30]. Anjangsana or hospitality in Javanese is known as "sanja" and its meaning refers to visiting (madhayoh) to a neighbor's house with the aim of talking to each other (omong-omongan) [31]. So anjangsana or silarurahmi (sanja) is a sign of harmony and at the same time a clear proof of mutual respect between two people (two parties) who are bound in a cord of friendship or brotherhood. The principle of harmony and the principle of respect for Javanese people is the basic rule for all forms of social interaction [32]. Harmony is a guarantee that peace (no conflict) in the level of social life is maintained, while respect is a 
guarantee that hierarchical order in the structure of social life is maintained [33]. So the ability to stay in touch in the context of forgiveness is evidence of good intentions to restore the atmosphere of harmony and mutual respect which could be damaged or interrupted due to the mistakes of others. The hospitality gave a guarantee that the hurt was healed and negative emotions were successfully controlled.

So the essence of the moral teachings of Javanese forgiveness in Serat Wedhatama and Serat Nitiprana is the embodiment of virtuous human character. Forgiveness as a response to the mistakes (bad deeds) of the other party, is lived and understood by virtuous humans as a way of struggle in the sense of testing and proving the quality of personal morals which are oriented to a state of inner life that is calm, serene, and balanced. Ability to overcome or at least control infidelity; negative emotions and evil desires as expressions of positive moral attitudes; patience, nrima, sincerity, and rila, and the ability to do good as an expression of generosity (compassion) is a prerequisite for forgiveness. Means forgiveness that refers to repayment, deletion or fusion (destruction without trace) mistakes or bad deeds of another party, or penalties in the form of criminal (torture) or demand for compensation as a consequence of mistakes considered to have been paid (paid in full) in principle is the result of calm mind and purity (purity) of the heart. Inner peace and purity of heart for virtuous persons is a form of true happiness and the main measure of happiness is to create peace, serenity, and harmony of life for themselves and radiate out giving warmth (creating joy), and giving coolness (creating peace of mind) for others human.

\section{CRITICAL ANALYSIS OF THE MORAL DIEMENSION OF JAVANESE FORGIVENESS}

Driyarakara said that the degree (dignity) of humans can be lifted as high as possible because of their intellect, but also open space can fall into humiliation as low as possible because of his intellect. Javanese forgiveness, especially in the Wedhatama Fiber and in the Nitiprana Fiber is the fruit of inner calm so that with patience, sincerity, nrima and rila can overcome or at least control the carelessness and at the same time encourage to do good to others who have done wrong. Concrete forms of forgiveness can be expressed through a variety of ways, both in the form of speech, self-delivery, and also concrete actions. Given the expression of forgiveness arising through physical signs, the possibility of misunderstanding about the substance of forgiveness itself is natural and understandable. To avoid the negative impact of misconceptions about the moral dimensions of Javanese forgiveness, the following below outlines the criteria for an action (forgiveness) that can be rationally justified [34].

First; Forgiveness is not a spontaneous act and is also not an obligation especially for the types of mistakes that are classified as serious or severe, but rather a choice among other possibilities in responding to mistakes. Forgiveness as a choice must be understood in the context of the process or the results of the research process and careful consideration of the three main elements of forgiveness, namely (a) acknowledgment of a mistake (bad behavior), whether intentional or unintentional mistake (b) the choice not to respond to others mistake with revenge or requests for compensation as a form of punishment, and (c) overcoming (or at least trying to control) negative emotions and evil desires, such as anger, hatred, malice, and so forth. In this first stage, the forgiving person must examine and carefully consider the difference between "recognation of mistakes" as the main element of forgiveness and "excusing, or condoning, or justifying, or pardoning, or forgetting" a mistake. Forgiveness is not identical with condonation, excuse, justification, pardon, and forgetting [35]-[36]. 
The victim has the right to punish the offender as a form of retaliation or request for compensation, but the victim deliberately chose not to use that right. Not punishing perpetrators is a form of respect for human dignity and solidarity with fellow human beings as weak creatures; open to doing wrong [37]-[38]. Forgiveness is a manifestation of awareness that the perpetrators as fellow human beings may not be used as objects of vengeance. Forgiveness is also interpreted as a form of awareness that all human beings can basically make mistakes so that forgiveness helps humans escape the cycle of revenge. Mistakes in the context of Javanese culture are a form of ignorance (durung ngerti), so the right response to the mistakes or bad deeds of others is to forgive, not punish. The ability to overcome the negative emotions and evil desires (angkara murka) and the ability to do good must be sincere (pure); must come from the deepest heart and be based on logical reasons so that it is morally worthy of praise. Creating a calm state of inner life is a reason that is morally praiseworthy as a basis for forgiveness. So the success of correctly understanding the main content of forgiveness determines forgiveness is morally commendable or conversely the failure to understand appropriately the main content of forgiveness makes forgiveness morally despicable and should be avoided.

Second; research and consideration of forgiveness must not be prolonged or protracted and must end with the decision to forgive. The decision to forgive must be right and wise and its size lies in freedom (independence) in making the decision.Independence in the decision to forgive is not due to blind desire without reason (as long as there is a will), but must be based on good will. A good will must contain a balance between knowledge of the contents of forgiveness and the actions that will be displayed. For example, the decision to re-establish social relations (hospitality) as a sign of forgiveness is not because of the inconvenience of feeling uncomfortable (shy), but because of reasons to learn to be a human being that is not controlled by evil desires and selfish attitudes. So forgiveness decision making is morally right and wise when born from a healthy mind (interior silence) and sincerity.

The act of forgiveness means practicing forgiveness or embodying forgiveness in a concrete action and the process often finds various obstacles that are difficult. Difficulty overcoming obstacles in the practice of forgiveness triggers doubts or doubts. Feeling confusion - uncertain - triggers to choose to retreat or cancel forgiveness. To retreat means to feel helpless and proof that there is no firmness and tenacity in facing and overcoming difficult obstacles. A person who has inner silence (mind), even though he is doubtful, even though he feels doubtful, even feels afraid, but does not retreat [39]. The virtuous person having inner silence - remains alert, remains steadfast and resilient and continues to forgive and incarnate it in concrete actions. So the act of forgoveness in practice must be understood in the context of continuous testing and verification of the quality of personal morals, namely the determination and tenacity in facing and overcoming various difficult obstacles. In short, forgiveness for a noble person is a form of determination and tenacity; not giving up when faced with difficult obstacles and must be practiced continuously in the reality of concrete life.

\section{CONCLUSION}

The essence of the moral teachings of Javanese forgiveness in Serat wedhatama and Serat Nitiprana is the embodiment of virtuous human character traits. Forgiveness for virtuous humans is lived and understood as a way of struggle to test and prove themselves as individuals who have entered the level of inner life that is calm, serene, and balanced. The ability to overcome or at least control negative emotions and evil desires (anger) as a manifestation of positive moral attitudes; patience, nrima, sincerity, and rila are forgiveness 
that comes from inner calm, although it is realized that this ability is still not enough as a condition of forgiveness with a positive moral status. Forgiveness for virtuous individuals must be perfected by doing good to the wrongdoers. Concrete manifestation of forgiveness for virtuous humans can be displayed in various ways, such as speech, writing, facial expressions or body movements (solah carry), and concrete actions. If the act of forgiveness is based on careful consideration and research (alleged prayoga), making appropriate decisions (empan boards), being steadfast and resilient in its implementation, then forgiveness helps realize the nature of virtuous human character to the highest degree, otherwise open forgiveness acts space can plunge humanity into humiliation as low as possible when done spontaneously (quickly); not mature in research and consideration, inappropriate in decision making, and hesitant in implementation.

\section{REFERENCES}

[1] Widada, Sukardi, Suwadji, D. Suwatna, K. Sidik, D. Sutana, and, Gina, "Javanase Dictionary (Bausastra Jawa)”, Tim Balai Bahasa Yogyakarta, PT. Kanisius, pp. 7, 25, 2011

[2] A. Bash, "Forgiveness and Christian Ethics”, Cambridge University Press, New York, pp. 31,2007

[3] C.1. Griswold, "Forgiveness: A Philosophical Exploration”, Published in the United States of America by Cambridge University Press, New York, pp. 10, 2007.

[4] E.V. Garcia, "Bishop Butler on Forgiveness and Resentment", The Journal of Value Inquiry, Vol 11 (No.10), pp. 1 - 19, 2011, http://www.philosophersimprint.org/011010/,.

[5] M.R. Holmgren, "Forgiveness and Retribution: Responding to Wrongdoing”, Cambridge: Cambridge University Press, pp. 32, 2012.

[6] B. Warmke, "Forgiveness and Responsibility", Electronic Dissertation, The University of Arizona, pp. 9, 2014, http://hdl.handle.net/10150/333086, ,

[7] Plutarch, [c. 100CE], "On the Control of Anger", in Moralia, (Vol. 6). Jeffrey Henderson (ed.), English translation by W.C. Helmbold, Cambridge, MA: Harvard University Press, pp. 89, 2000.

[8] D. Sussman, "Kantian Forgiveness", Kant-Studien, 96(1): 85-107, 2005, doi:10.1515/kant.2005.96.1.852005

[9] O. Ware, "Forgiveness and Respect for Persons", American Philosophical Quarterly, 51(3), pp. 247-260, 2014.

[10] Z. Arif, "Baratayudha War; The Great War of the Pandava Kurawa, Pustaka Jawi, Yogyakarta, pp. 149, 2017.

[11] N. Mulder, "Private and Community in Java", Sinar Harapan, Jakarta, pp. 35, 1985.

[12] Suharsono \& H.M.E. Widiatmadi, Characteristics of Javanese Power; Analysis of Drama Mangir's Essay by Pramoedya Ananta Toer, First Matter, 2000, Gramedia Popular Literature, Jakarta, Research Report, Not Published, pp. 40, 2007.

[13] Pranowo, "Javanese Language Phrases as Supporters Formation of National Culture", Indonesian Linguistics, 2, pp. 269 - 289, 2003.

[14] N. Mulder, "Private and Community in Java", Sinar Harapan, Jakarta, pp. 53, 1985.

[15] BBC New, Indonesia, "Event 65 and PKI; Faces of Victims and Perpetrators" https://www.bbc.com/indonesia/berita_indonesia/2016/06/160531_indonesia_kuburan_ masal_jegong, 3 June 2016.

[16] A. Any, "Uncovering of Serat Wedotomo", CV. Aneka Ilmu, Semarang, pp. 39, 46, 1983. 
[17] R. Soedjonoredjo, “Wedhatama Winardi”, PT. Citra Jaya Murti, Surabaya, pp. 30, 48, 1991.

[18] A. Chodjim, "Serat Wedhatama; For Our Time”, PT. Betara Aksara Cahaya, Tangerang Selatan, pp. 276, 2016

[19] Kamajaya (Translator), "Serat Nitiprana by R. Ng. Yasadipura”, Ministry of Education and Culture, Jakarta, pp. 1, 1979.

[20] W.J.S. Poerwadarminta, “Javanese Dictionary (Bausastra Jawa)”, pp. 7, 1939, https://www.sastra.org/.

[21] F.M. Suseno, "Javanese Ethics, An Analysis of the Philosophy of the Wisdom of Javanese Life”, Jakarta: Gramedia, pp. 140, 1996.

[22] S. Endraswara, “Javanese Soul Sciences: Aesthetics and Taste of Javanese Soul”, Narasi, Yogyakarta, pp. 38, 2012.

[23] F.M. Suseno, "Javanese Ethics, An Analysis of the Philosophy of the Wisdom of Javanese Life”, Jakarta: Gramedia, pp. 142 - 143, 1996.

[24]R. Poerwanto, "Serat Nitiprana Piwulang Budi Luhur", https://jayabaya.wordpress.com/2006/07/12/serat-nitiprana-piwulang-budi-luhur/2006.

[25] S. Endraswara, “Javanese Soul Sciences: Aesthetics and Taste of Javanese Soul”, Narasi, Yogyakarta, pp. 173, 2012.

[26] A. Chodjim, "Serat Wedhatama; For Our Time”, PT. Betara Aksara Cahaya, Tangerang Selatan, pp. 201, 2016

[27] W.J.S. Poerwadarminta, “Javanese Dictionary (Bausastra Jawa)”, pp. 403, 1939, https://www.sastra.org/

[28] Suharsono \& DP. B. Susetya, "Descriptive Study of the Concept of Forgiveness Based on Javanese Culture", Research Report, Not Published, pp. 31, 2016.

[29] S. Endraswara, "Positive Thinking of Javanese”, Narasi, Yogyakarta, pp. 191, 2016.

[30] Big Indonesian Dictionary (Kamus Besar Bahasa Indonesia), Second Edition, Ninth Printing, PT. Balai Pustaka, Jakarta, pp. 46, 940, 1997.

[31] W.J.S. Poerwadarminta, “Javanese Dictionary (Bausastra Jawa)”, pp. 544, 1939, https://www.sastra.org/

[32] F.M. Suseno, "Javanese Ethics, An Analysis of the Philosophy of the Wisdom of Javanese Life”, Jakarta: Gramedia, pp. 38, 1996.

[33] F.M. Suseno, "Javanese Ethics, An Analysis of the Philosophy of the Wisdom of Javanese Life”, Jakarta: Gramedia, pp. 39, 60, 1996.

[34] A. Sudiarja, B. Subanar, ST. Sunardi, and T. Sarkim (Editor), "Complete Works of Driyarkara; Thinking Essays Involved in the Struggle of His Nation”, PT. Gramedia Pustaka Utama, Jakarta), pp. 582 - 585, 2006.

[35] J.G. Murphy, "Forgiveness, Reconciliation and Responding to Evil: A Philosophical Overview”, Fordham Urban Law Journal, Vol 27 Issue 5: pp. 1353 - 1366, 1999.

[36] Warmke, "Forgiveness and Responsibility", Electronic Dissertation, The University of Arizona, pp. 13, 2014, http://hdl.handle.net/10150/333086

[37] E. Gerrad \& D. McNaugthon, "In Defence of Unconditional Forgiveness", Proceedings of the Aristotelian Society, vol. 103, no. 1, pp. 39-60, 2003

[38] O. Ware, "Forgiveness and Respect for Persons", American Philosophical Quarterly, 51(3), pp. 248, 2014

[39] A. Sudiarja, B. Subanar, ST. Sunardi, and T. Sarkim (Editor), "Complete Works of Driyarkara; Thinking Essays Involved in the Struggle of His Nation”, PT. Gramedia Pustaka Utama, Jakarta), pp. 584 - 585, 2006. 